\title{
Rare Earth Elements Assessment in the Granitoids of Part of Southwestern Nigeria
}

\author{
Victoria B. Omotunde, Akinade S. Olatunji and Maryam O. Abdus-Salam
}

\section{ABSTRACT}

The Rare Earth Elements (REE) composition of granitoids in and around Ila-Orangun area Southwestern Nigeria was assessed in order to ascertain their potential for possible exploitation. Detailed lithological mapping of the area was undertaken followed by whole rock geochemical analysis of representative samples of the granitoids using Inductively Coupled Plasma Mass Spectrometry (ICP-MS) technique. Petrographic study of the samples was carried out as well as the interpretation of the geochemical data using diverse geochemical discrimination plots.

The rock units mapped were biotite granite gneiss, granite gneiss and hornblende biotite granite. Biotite hornblende gneiss, quartzite, talcchlorite-tremolite-schist, mica schist and pegmatites were the surrounding country rocks.

The REE concentrations (in ppm) revealed higher concentrations of the light REEs compared to the heavy REEs. The fractionation ratio, $(\mathrm{La} / \mathrm{Yb})_{\mathrm{N}}$ ranged from 4.35-15.04 (granite gneiss) and 13.78-18.48 (hornblende biotite granite) indicating enrichment in LREEs over the HREEs. The spider plot for the REEs also showed that the granitoids are LREE-enriched and HREE-depleted suggesting fractional crystallisation and a distinct negative Eu anomaly indicating plagioclase fractionation. Enrichment plot also revealed that the REEs in the granitoids are significantly enriched. Comparison with other areas showed that the granitoids of the study area especially the hornblende biotite granite has higher concentrations of REEs and may be a possible pointer of REE mineralisation.

Published Online: October 29, 2020

ISSN: $2684-446 \mathrm{X}$

DOI : $10.24018 /$ ejgeo.2020.1.5.79

Victoria B. Omotunde*

Department of Geosciences, Pan African University of Life and Earth Sciences Institute, University of Ibadan, Nigeria.

(e-mail: vicomotunde@gmail.com)

Akinade S. Olatunji

Department of Geology, University of Ibadan,

Nigeria.

(e-mail: akinadeshadrach ${ }^{\circledR}$ yahoo.com)

\section{Maryam O. Abdus-Salam}

Department of Geosciences, Pan African University of Life and Earth Sciences Institute, University of Ibadan, Nigeria.

Department of Geology, The Polytechnic Ibadan, Nigeria.

(e-mail: maryamakinsanya ${ }^{@}$ gmail.com)

*Corresponding Author

Keywords: Geological mapping, Granitoids, Mineralisation, Rare earth elements.

\section{INTRODUCTION}

The search for REE has attracted increased urgency as their use in modern technological applications [1] continue to increase and the global reserve and stockpile are dwindling. The REE have found extensive use in the electronic industry especially in the production of mobile phones, energy-saving lightings, laser, superconductors, flat-screen TVs; several applications in the Military, medicine as well as in environmental studies, where they are also in very high demand in renewable energy resources and hybrid gaselectric automobiles manufacturing.

Researchers have mostly focused on the existing geologic environments for REEs which are carbonatites [2]-[4], alkaline igneous systems [5], ion-absorption clay deposits [6] and monazite-bearing placer deposits [7], [4] as sources for REEs. The increased thirst for REEs has led to more exploration and exploitation of REEs in areas where they have not been traditionally exploited as they have become the latest mineral resource of this century [8]. This work is therefore aimed at investigating the REE potentials of the granitoids dotting the landscape in southwestern Nigeria using the study area as a case study.

\section{Study Area And Geological Setting}

The study area is defined by the latitudes $08^{\circ} 00^{\prime} 00^{\prime \prime} \mathrm{N}$ and $08^{\circ} 04^{\prime} 00^{\prime \prime} \mathrm{N}$ and longitudes $04^{\circ} 49^{\prime} 00^{\prime \prime} \mathrm{E}$ and $04^{\circ} 57^{\prime} 00^{\prime \prime}$ $\mathrm{E}$, Ila-Orangun and Oyan are the major towns within the area and these are surrounded by several minor settlements. The vegetation of the area is typical tropical rainforest characterised by tall trees, herbs and twigs, tall grasses and shrubs, and tropical climate with typical wet and dry seasons. The area is underlain by the Basement Complex of Nigeria which consists of Migmatite-Gneiss Complex (MGC) [9] with ages ranging from Liberian to Pan-African; the Upper Proterozoic supracrustal rocks known as the Schist belts [10] and the Syn to Late tectonic granitic rocks which intruded the MGC and the Schist belts [11], [12]. The Ilesha Schist belt [13], in which the study area is located (Fig. 1), consists largely of schistose rocks [14], amphibolite, amphibole schists and pelitic schists with associated granite, gneiss and pegmatite in the western units of the Ife fault zone, and quartzite, quartz schist, quartzofeldspathic gneiss and minor iron-rich schists and quartzites in the eastern unit.

The mapped lithological units are Mica schist (muscovite and biotite schist), talc schist, quartzite, biotite hornblende gneiss, biotite granite gneiss, granite gneiss, porphyritic 
granite and pegmatites. (Fig. 2). These outcrops occur in varying sizes and dimensions.

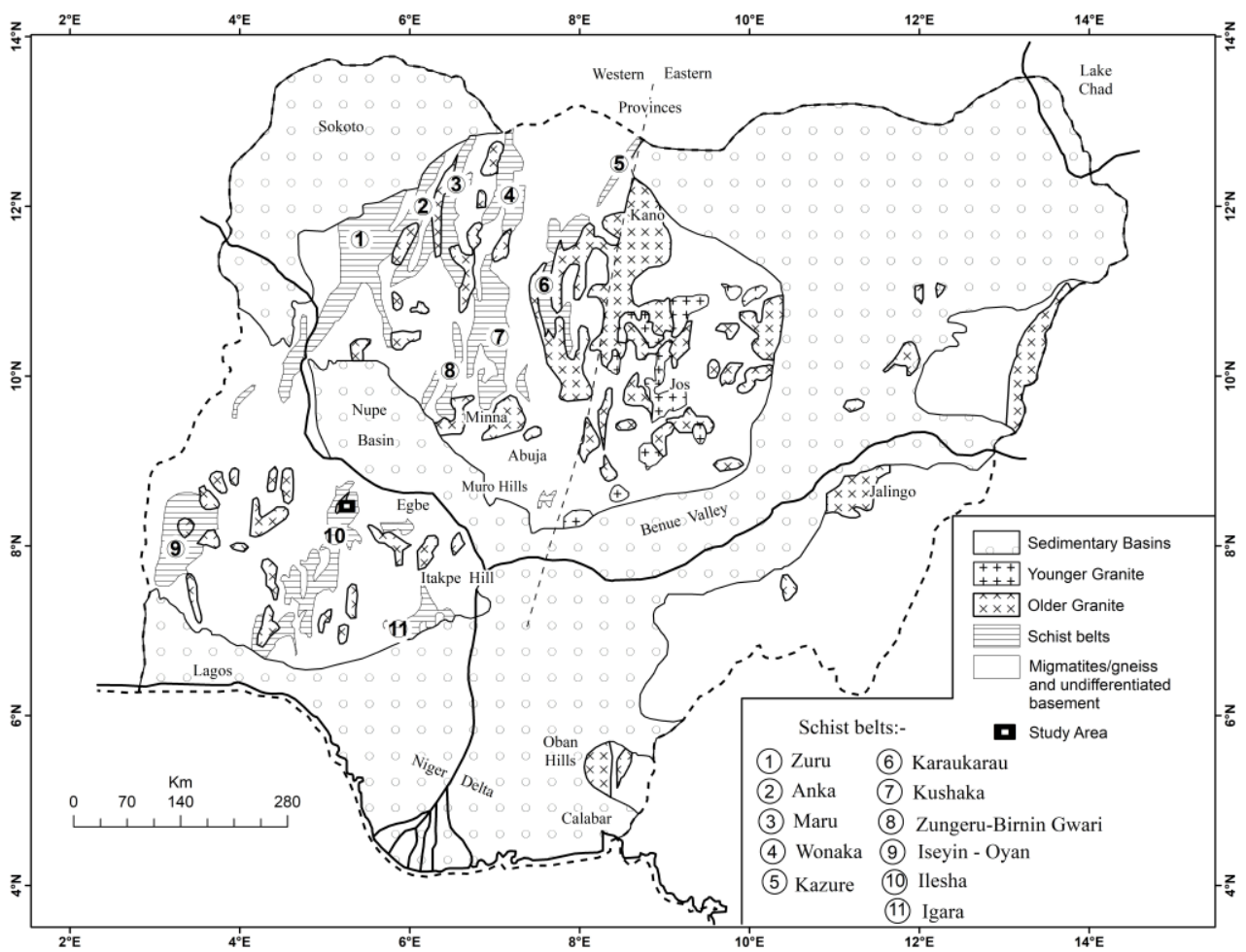

Fig. 1. Localization of the study area on the regional geological map of Nigeria. (Modified after [13]).

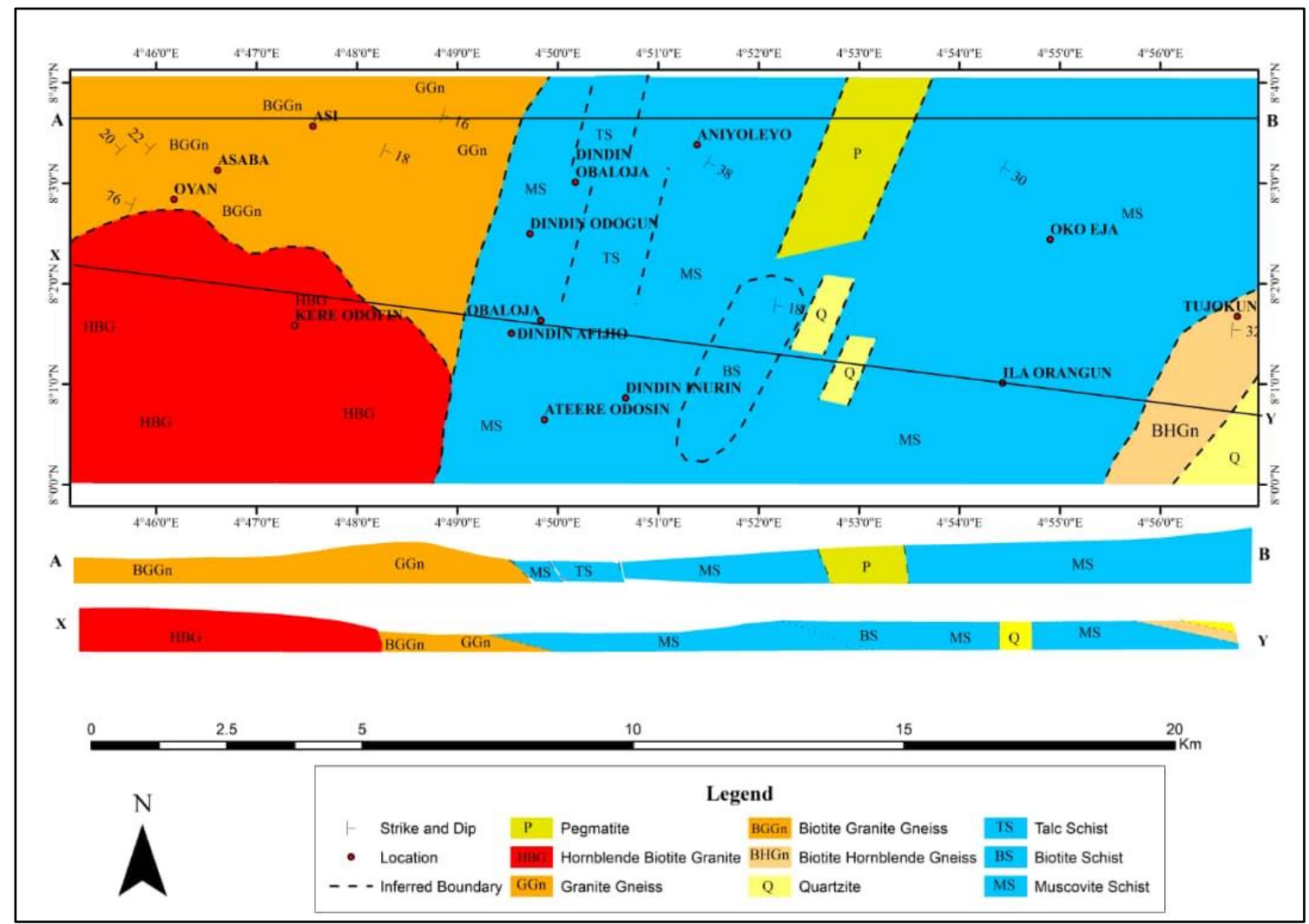

Fig. 2. Geological map of the study area.

\section{Methodology}

Geological mapping was carried out on a scale of 1:25000 using a topographic map as the base map. Compass traverse through existing major and minor roads, footpaths and bush clearing was used for the geological mapping, while the Global Position System (G.P.S) was used for determining the geographic coordinates of the exposed outcrops. Field observations and description of features were properly recorded. 
Representative rock samples were collected and prepared into thin sections. Representative samples of granitoids were crushed, pulverised and analysed for their major, trace and REE at the Bureau Veritas Mineral Services, Vancouver, Canada using ICPMS with the aid of lithium borate fusion digestion method.

\section{RESUlts AND Discussions}

\section{A. Field occurrences and Petrographic description of the granitoids in the study area.}

The granitoids mapped out were the granite gneisses, biotite granite gneiss and porphyritic granite (Fig. 3). These rocks are restricted to the western part of the study area. Detailed modal mineralogical compositions of the rocks are presented Table 1 .

Granite gneisses: These outcrops were found in the northwestern part of the area. They are low-lying, extensive and while some are well exposed, a few have been extremely weathered.

Biotite granite gneiss: This trends in the NE-SW direction typical of the Pan-African orogeny and constituting about 5\% of the study area. The outcrops are medium to coarse grained and largely exhibit weak to slightly strong foliation defined by alternating mafic (biotite and hornblende) and felsic minerals (quartz and feldspars). The identified minerals include quartz, feldspars, biotite and muscovite.

Granite gneiss shares boundary with the biotite granite gneiss in the northwestern part of the area, to the east by mica schist and to the south by the porphyritic granite. They are low-lying, extensive and moderately weathered outcrops (Fig. 3). Quartz and pinkish feldspar (K-feldspar), and subordinate muscovite and sparse biotite were the identified minerals.

Hornblende biotite granite: They are porphyritic, coarse grained, leucocratic, highly weathered and occurred as batholith/plutons in the south western part of the area. Mineral lineation in the rocks are defined by K-feldspars and are aligned in the NE-SW direction. Abundant quartz and Kfeldspar (mostly microcline) with subordinate plagioclase, biotite and hornblende were observed on the granites (Fig. 4). The potassic feldspars occur as the phenocryst, while quartz, biotite and hornblende occur as groundmass matrices. Biotite occurred as light to dark brown and with mottled appearance and bird's eye extinction, and together with quartz and hornblende formed the matrices (groundmass).
TABLE 1: PETROGRAPHIC ANALYSIS OF THE ROCK UNITS

\begin{tabular}{|c|c|c|c|}
\hline Minerals & $\begin{array}{c}\text { Biotite granite } \\
\text { gneiss }\end{array}$ & $\begin{array}{l}\text { Granite } \\
\text { gneiss }\end{array}$ & $\begin{array}{c}\text { Porphyritic } \\
\text { granite }\end{array}$ \\
\hline Quartz & 35 & 24 & 36 \\
\hline K-Feldspar & 28 & 30 & 21 \\
\hline Plagioclase & 6 & 22 & 7 \\
\hline Biotite & 21 & 8 & 20 \\
\hline Muscovite & 6 & 4 & - \\
\hline Hornblende & - & - & 10 \\
\hline Garnet & - & 1 & 2 \\
\hline Zircon & 2 & 1 & 1 \\
\hline Opaque & 2 & 10 & 3 \\
\hline
\end{tabular}
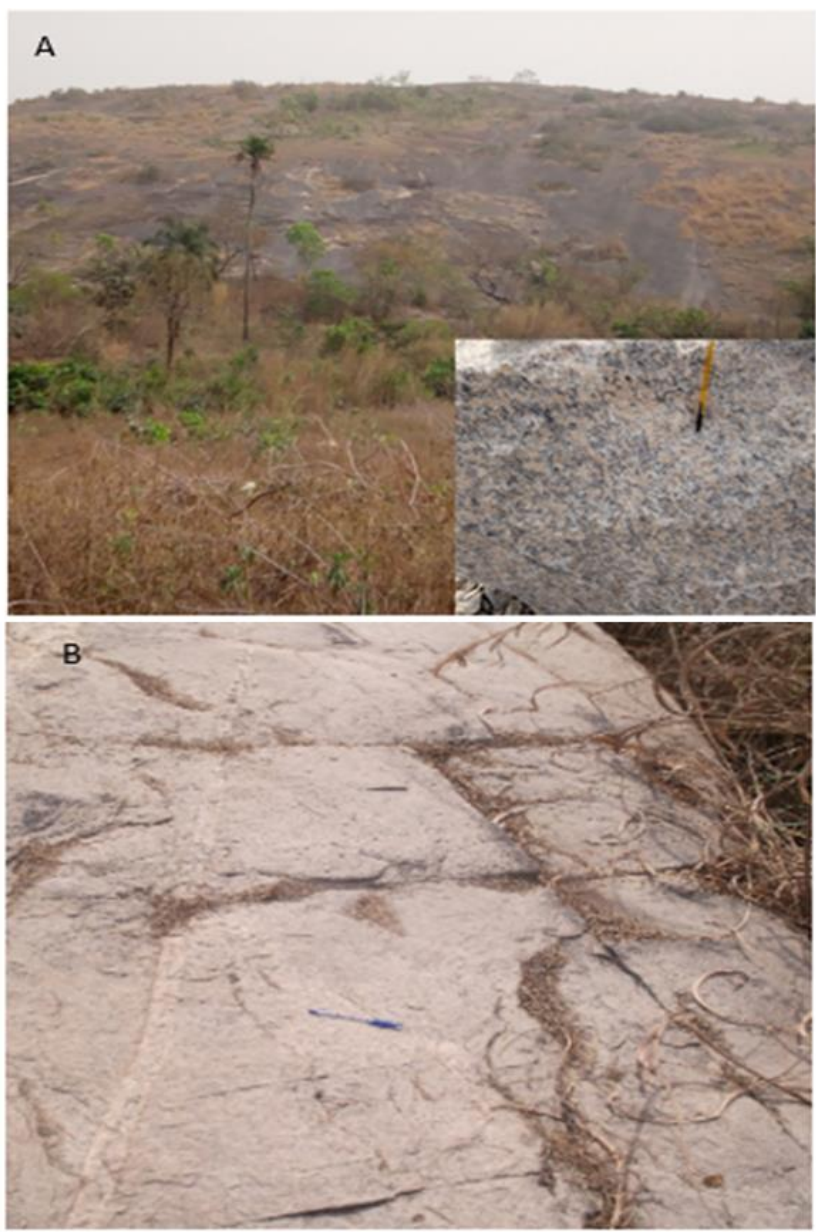

Fig. 3. Field occurrences of the granitoids a) Porphyritic Granite b) Granite gneiss in the study area.

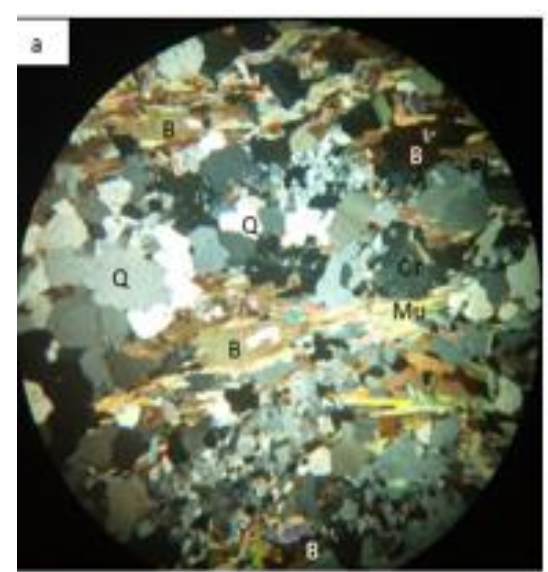

Fig. 4. Photomicrographs of (a) Biotite granite gne
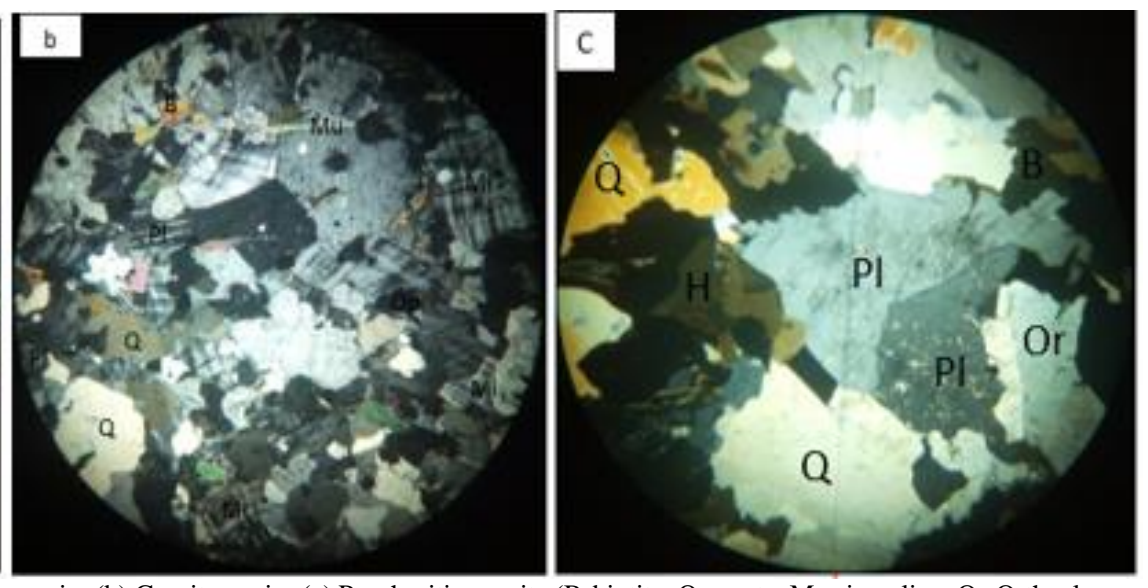

Pl-Plagioclase, Mu-muscovite, H-hornblende) 


\section{B. Geochemistry of the granitoids}

Results from the geochemical analysis revealed a broad range of values (Table 2) with $\mathrm{SiO}_{2}$ ranging from 65.2 to $72.22 \%, \mathrm{Al}_{2} \mathrm{O}_{3} 9.3$ to $15.21 \%, \mathrm{Fe}_{2} \mathrm{O}_{3} 1.54$ to $7.24 \%, \mathrm{CaO}$ 0.79 to $3.16 \%, \mathrm{MgO} 0.2$ to $0.87 \%$ and $\mathrm{K}_{2} \mathrm{O} 2.1$ to $7.72 \%$. $\mathrm{SiO}_{2}$ is the most abundant major oxide in all the rock types with the highest concentration found in the porphyritic granite (72.22\%) and the lowest concentration $(65.2 \%)$ in the biotite granite gneiss. $\mathrm{TiO}_{2}, \mathrm{P}_{2} \mathrm{O}_{5}$ and $\mathrm{MnO}$ are the least abundant major oxides with an average concentration of less than $1 \%$ in all the rock samples. Varying concentrations were recorded for $\mathrm{CaO}$ and $\mathrm{MgO}$ with the values of $\mathrm{CaO}$ being higher than $\mathrm{MgO}$. This could also be as a result of remobilization of preexisting minerals in the rock and/or the composition of the parent material before metamorphism [15]. The major oxide concentration for the granite gneisses has similar chemistry to the varieties of gneisses from the western part of Nigeria [16], Abeokuta [17], Kafur-Yari-Bori-Tsiga area [18] and Main central thrust (MCT) Zone, Kumaun Himalaya, India [19], while the granitic rocks of the study area have similar chemistry with those from Jiangxi province, Southern China [20].

The trace elements results are presented in Table 2 with Ba, $\mathrm{Zr}, \mathrm{Rb}, \mathrm{Sr}, \mathrm{Nb}, \mathrm{Hf}, \mathrm{Zn}, \mathrm{V}$ and $\mathrm{Th}$ showing elevated concentrations (Table 2). For the granitoids, Ba ranged from 214-1034ppm, Zr ranged from 241.9-2507.8ppm with the highest concentration $(2507.8 \mathrm{ppm})$ recorded in the porphyritic granite. $\mathrm{Cu}$ ranged from $0.4-15.7 \mathrm{ppm}$ with biotite granite gneiss showing the highest value of $15.7 \mathrm{ppm}$. $\mathrm{Pb}, \mathrm{Ta}$, $\mathrm{Ni}, \mathrm{Co}$ and $\mathrm{Be}$ are generally low in all the granitoids Th concentrations are highest in the porphyritic granites contains the most elevated concentrations of $\mathrm{Th}$ and indication of possible presence of radioactive minerals. The rock samples showed relative abundance of zinc with the highest found in the biotite granite gneiss (171 ppm). In all the samples, the concentration of tin ( $\mathrm{Sn}$ ) ranged from 3-11 ppm, while $\mathrm{Rb}$ ranged from 167.5 to $277.1 \mathrm{ppm}$. The variation in concentrations of these elements may be attributed to the composition of the magma that formed the pre-existing rocks or metamorphism of the country rocks.

The trace elements within the granitoids in the study area have similar chemistry with granitoids from Ilesha area [21], Temidire-Afao around Ikere-Ekiti [22] and also compared well with the average granite composition in the continental crust [23].

\section{Petrogenesis and Tectonic Setting}

Discrimination plots and diagrams were used to determine the origin and tectonic settings of the rock types in the study area. On the discrimination plot of [24] where $\mathrm{TiO}_{2}$ is plotted against $\mathrm{SiO}_{2}$, most of the samples fell within the igneous field implying igneous origin for the granitoids (Fig. 5A). The plot of $\mathrm{Na}_{2} \mathrm{O}+\mathrm{K}_{2} \mathrm{O}$ against $\mathrm{SiO}_{2}$ after [25] revealed granitic progenitor for the granitoids (Fig. 5B).

From the geochemical data, the ratio $\mathrm{Na}_{2} \mathrm{O} / \mathrm{K}_{2} \mathrm{O}$ ranged from $0.29-1.24 \%$ with their alumina content greater than the alkalis. The Aluminum Saturation Index of [26] therefore revealed that the porphyritic granites were metaluminous in nature while the biotite granite gneiss and the granite gneiss were mostly peraluminous (Fig. 5C). This shows that their granitic protolith may have suffered magma contamination.
The presence of hornblende in the porphyritic granite may have also contributed to their metaluminous nature [26], thereby suggesting I-type granite as supported by the discrimination plots of [24].

The geotectonic discrimination plots using trace elements after [27] revealed that the granitoids plotted in the 'within plate granite' field as shown on the $\mathrm{Rb}-(\mathrm{Ta}+\mathrm{Yb})$ plot (Fig. 5D). This generally imply that the granitoids must have been derived from enriched mantle sources and crustal materials involvement [27] and that the granitoids got emplaced during an overlapping tectonic setting related to final stage of orogeny and are said to be late collisional to post collisional granites [28], [29].

\section{Rare earth element geochemistry}

The REE concentration of the granitoids (granite gneiss, biotite granite gneiss and the porphyritic granite) is presented in Table 2. Generally, the concentrations of the REE are higher in the hornblende biotite granite compared to the gneisses. The biotite granite gneisses recorded the lowest concentrations of the REE among the granitoids. The LREE (La-Nd) within the granite gneisses are higher than the HREE (Sm-Lu). The ratio $(\mathrm{La} / \mathrm{Yb}) \mathrm{N}$ ranged from 4.35-15.04 showing enrichment in LREE and depletion in HREE. The enrichment in LREE and depletion in HREE with negative $\mathrm{Eu}$ anomaly (Eu/Eu* ranged from 0.27-0.38) implies moderate fractionation of the source rocks and preservation of alkali and plagioclase feldspar [23].

The sum of the LREE, HREE, total REE and fractionation ratios (Table 2) for the hornblende biotite granite revealed that $\sum$ LREE ranged from 713.03-2151.94, $\sum$ HREE ranged from 59.67-189.02, while $\sum$ REE ranged from 772.692340.96. This implies fractional crystallisation with the crystallising magma sourced from the upper continental crust.

The presence of garnet in the granite may also have contributed to the depletion of HREE and subsequent enrichment in the LREE. The ratios $(\mathrm{La} / \mathrm{Yb}) \mathrm{N}$ and $(\mathrm{La} / \mathrm{Sm}) \mathrm{N}$ which are fractionation indices of LREE/HREE, ranged from 13.78-18.48 and 4.06-4.44, respectively indicating that the granites are LREE-enriched and HREE-depleted.

Variation plots of $\mathrm{La}$ and $\mathrm{Yb}$ relative to $\mathrm{La} / \mathrm{Yb}$ ratio in the granitoids (Fig. 6a and 6b) also indicated enrichment of LREE and depletion of HREE as displayed by the strong correlation in the La-La/Yb plot and a weak correlation in the $\mathrm{Yb}-\mathrm{La} / \mathrm{Yb}$ plot. Normalized REE plots using Chondrite values [24] (Fig. 6c) revealed continental crustal sourced materials as all the REE had values above 1 (Wedepohl,1995). Slight enrichment in the concentrations of Sm, Gd and Dy (Middle Rare Earth Elements (MREE) confirms the presence of hornblende in the granites. Generally, rocks that are LREE-enriched and HREE-depleted are usually associated with fractional crystallization of magma sourced from the continental crust. 
TABLE 2: GEOCHEMICAL COMPOSITIONS OF THE GRANITOIDS IN THE STUDY AREA (MAJOR OXIDES IN WT.\% WHILE TRACE AND RARE EARTH ELEMENTS IN

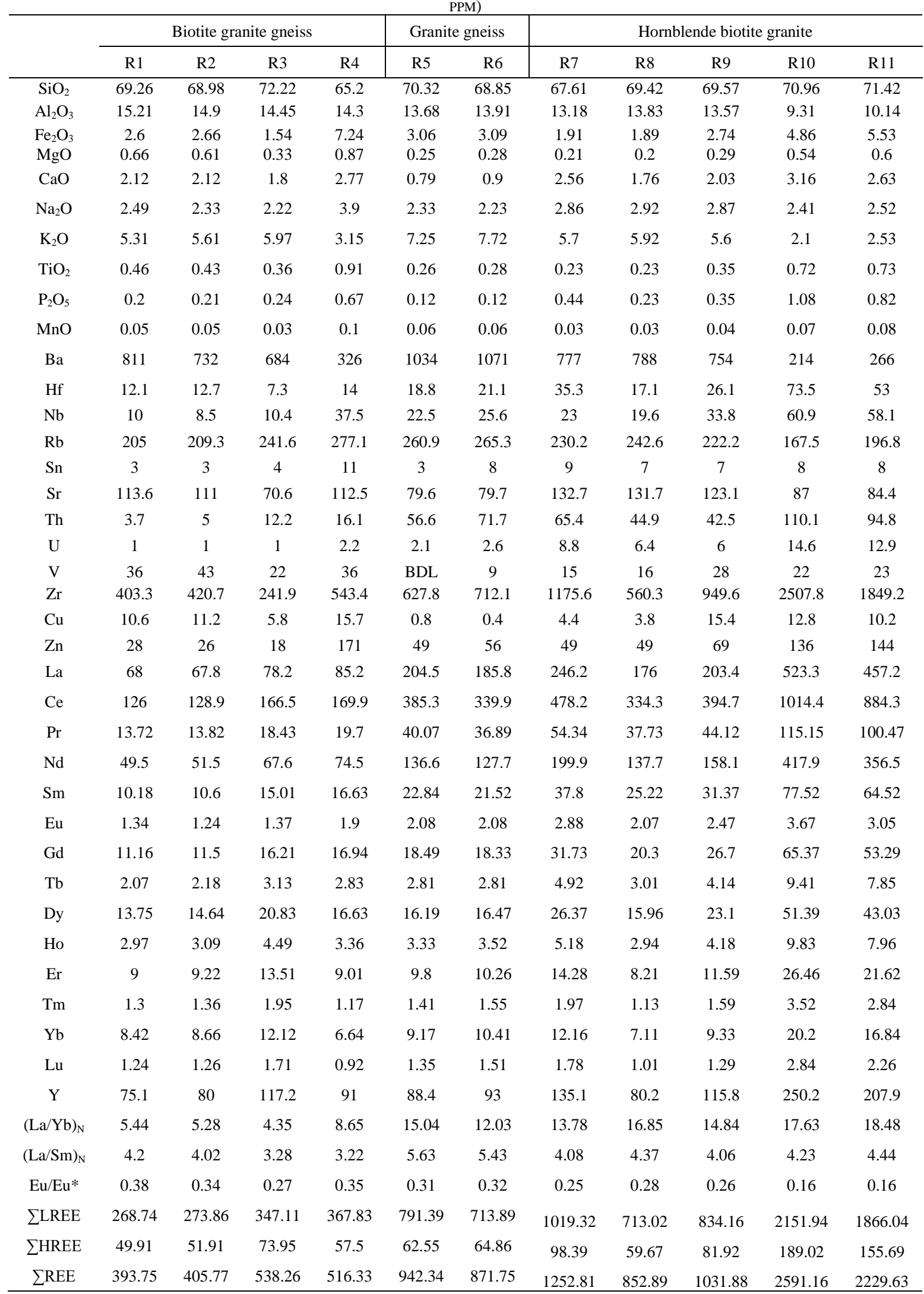


European Journal of Environment and Earth Sciences www.ej-geo.org
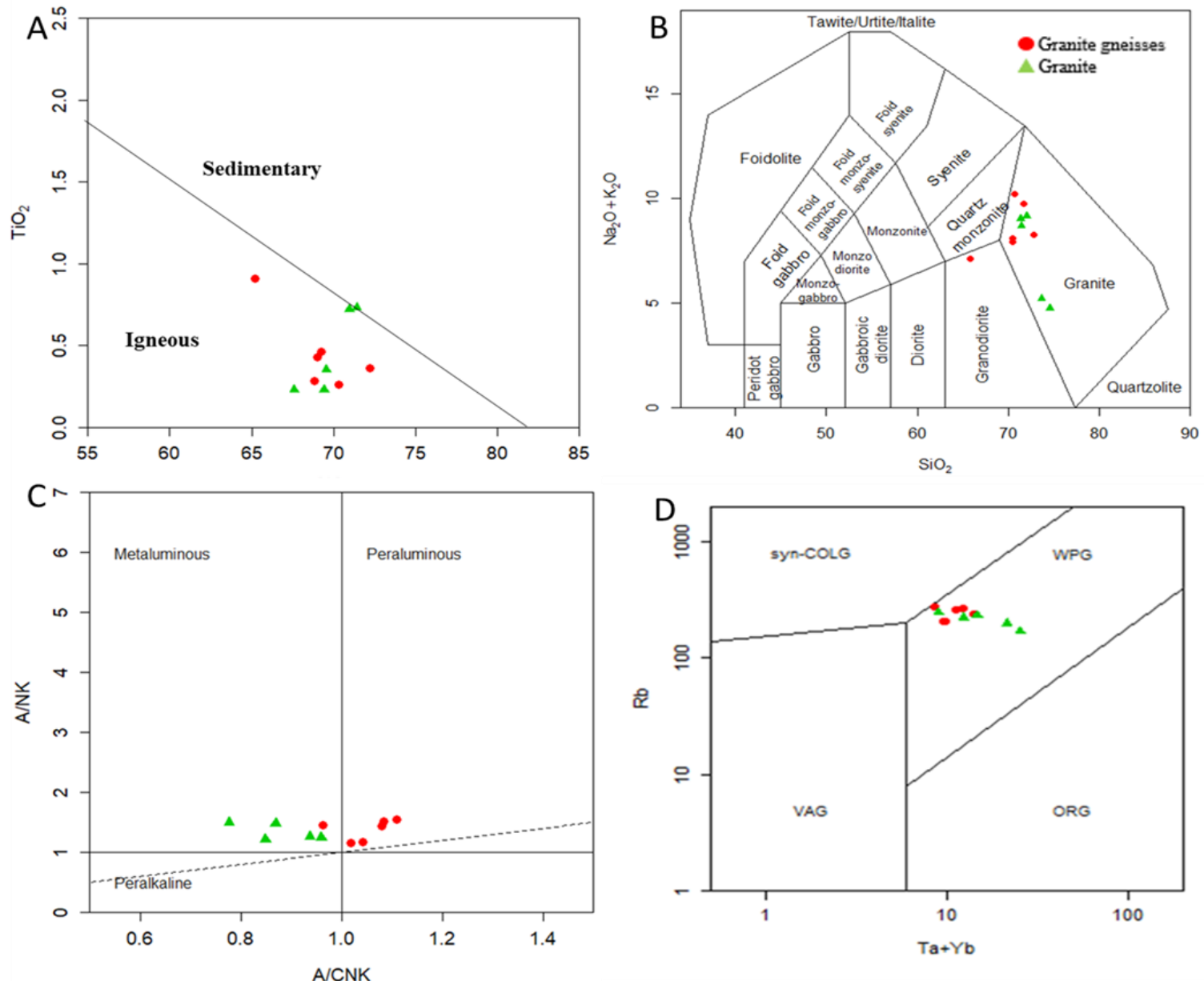

Fig. 5. Discrimination plots of (a) $\mathrm{TiO}_{2}$ versus $\mathrm{SiO}_{2}$ after Tarney, 1977 (b) $\mathrm{Na}_{2} \mathrm{O}+\mathrm{K}_{2} \mathrm{O}$ versus $\mathrm{SiO}_{2}$ plot showing the igneous precursor of the granitoids after Middlemost,1994 (c) $\mathrm{Al}_{2} \mathrm{O}_{3} /\left(\mathrm{CaO}+\mathrm{Na}_{2} \mathrm{O}+\mathrm{K}_{2} \mathrm{O}\right)$ versus $\mathrm{Al}_{2} \mathrm{O}_{3} /\left(\mathrm{Na}_{2} \mathrm{O}+\mathrm{K}_{2} \mathrm{O}\right)$ (after Shand 1943) (d) Geotectonic discrimination plots for the granitoids [27].

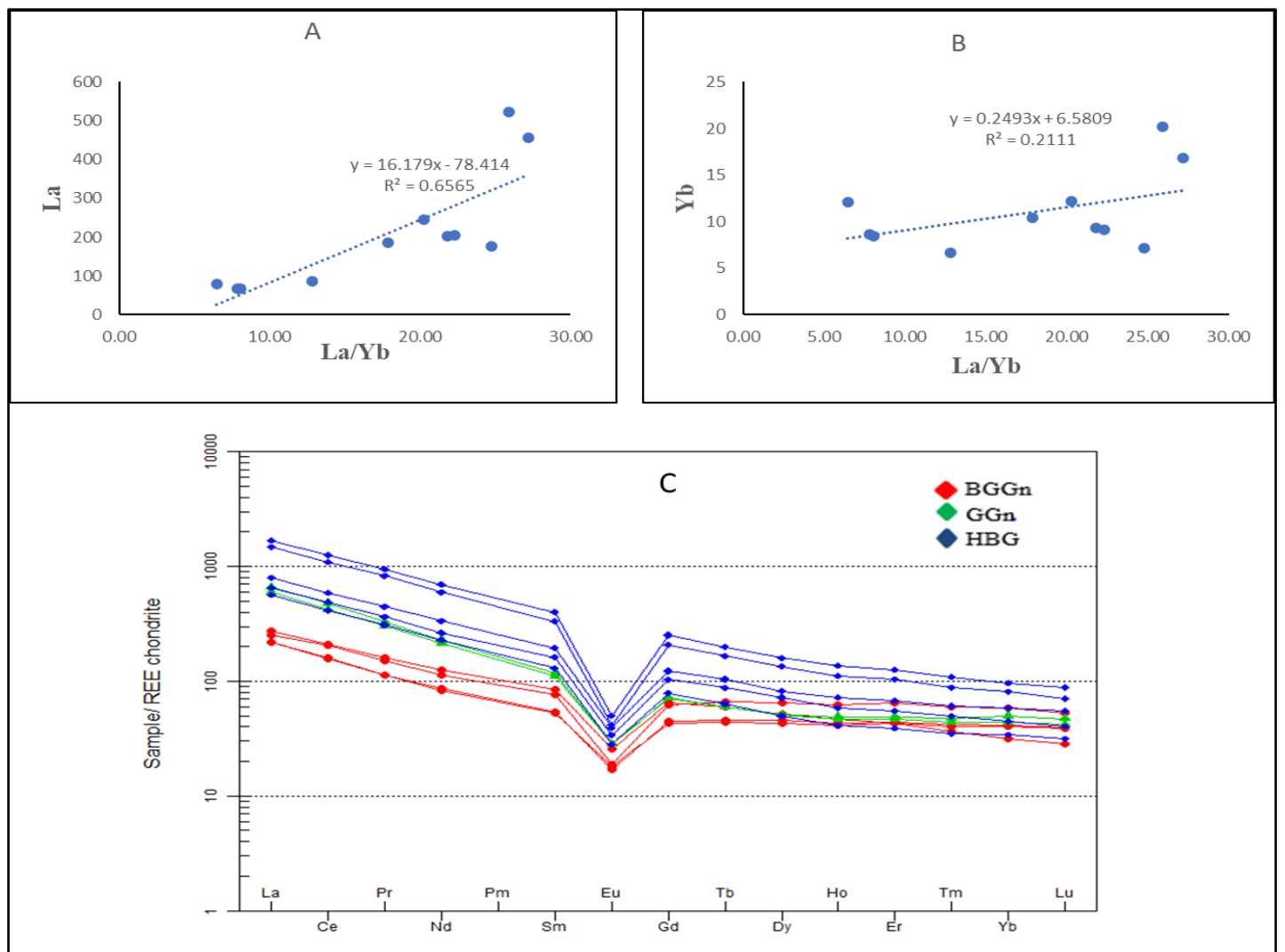

Fig. 6. (a) Variation plot of La relative to La/Yb ratio (b) Variation plot of $\mathrm{Yb}$ relative to La/Yb ratio (c) Spider plot normalised by REE Chondrite [30] for the granitoids in the study area (BGGn-Biotite granite gneiss, GGn-Granite gneiss and HBG-Hornblende biotite granite. 


\section{E. REE Mineralisation Potential}

The concentration of the REEs within the granitoids were further compared with those from areas where mineralisation was proven or suspected in order to determine their mineralisation potential. The REE concentrations in this study area was observed to be greater than concentration of REEs in the granitoids of those of Dingnan, Southern China [20], a prominent REE mining region in China [31]. The REE in the granitoids was also observed to be higher than the REE in the granitoids of Guguruji and Tegina area [32], Obudu Plateau [33] and parts of Komu area [34] (Table 3). The REE concentration was however observed to be slightly lower than those of the Precambrian alkali granite of the Arabian shield, Umm al Birak [5]. It can therefore be safely speculated that the granitoids of the area, especially the hornblende biotite granites, may be a possible potential source of REE exploitation.

Comparative study of the range of total REE ( $\Sigma$ REE) in granites of the study area and those from other areas (Table
4.3); 168.18-428.54 (Dingnan, southern China), 67.62330.08 (Masamba granites), 6.98-290.75 (Komu granite) and $772.69-2340.96$ (study area) also suggests that the granites in the study area is a potential source for rare earth elements.

The REEs in the granitoids of the study area are appreciably enriched than those in the Dingnan area of Southern China where mining is currently on going. Also, compared to the Komu area of southwestern Nigeria where significant concentrations of REEs had been reported, REEs in the granitoids of the study area is expressively enriched as most of the enrichment index are greater than 1 (Fig. 7).

The REEs within the granitoids of the study have been contributed through magmatic and hydrothermal processes [35], [36] that have occurred at the end phase of crystallization and magma differentiation during fractional crystallization of magma. The hydrothermal fluids carry within them these rare earth elements and are responsible for their concentration and deposition within the granitoids.

TABLE 3: COMPARISON OF THE REE CONCENTRATIONS IN THE STUDY AREA WITH OTHER GRANITOID

\begin{tabular}{|c|c|c|c|c|c|c|c|c|c|c|}
\hline & \multicolumn{2}{|l|}{1} & \multicolumn{2}{|l|}{2} & \multicolumn{2}{|l|}{3} & \multirow{2}{*}{$\frac{4}{\text { Range }}$} & \multirow{2}{*}{$\begin{array}{c}5 \\
\text { Range }\end{array}$} & \multirow{2}{*}{$\frac{6}{\text { Range }}$} & \multirow{2}{*}{$\begin{array}{c}7 \\
\text { Range }\end{array}$} \\
\hline & Range & Mean & Range & Mean & Range & Mean & & & & \\
\hline $\mathrm{La}$ & $176-523.3$ & 285.2 & $33.4-101.00$ & 63.08 & $0.90-81.9$ & 45.60 & $588-663$ & 7.1-91.4 & $40.1-285$ & 7.6-75.1 \\
\hline $\mathrm{Ce}$ & $334.3-1014.4$ & 547.3 & $73.2-196.00$ & 128.24 & $2.9-132.0$ & 80.65 & $1797-1229$ & $44.3-181$ & $71.2-595$ & $16.6-157$ \\
\hline $\operatorname{Pr}$ & $36.89-115.15$ & 61.3 & $8.11-20.00$ & 13.7 & $0.3-13.4$ & 9.05 & $92-118$ & $1.42-19.4$ & $8.67-64.5$ & $2.11-17.2$ \\
\hline $\mathrm{Nd}$ & $127.7-417.9$ & 219.2 & $30.4-71.30$ & 50.6 & $1.3-50.5$ & 32.7 & $427-752$ & $6.2-60.5$ & $30.6-204$ & $8.9-53$ \\
\hline $\mathrm{Sm}$ & $21.52-77.52$ & 40.1 & $6.49-13.60$ & 10.47 & $0.4-10.8$ & 6.43 & $75-169$ & $1.6-10.4$ & $5.59-33.1$ & $2.3-7.18$ \\
\hline $\mathrm{Eu}$ & $2.07-3.67$ & 2.6 & $0.22-1.65$ & 0.59 & $0.08-1.94$ & 1.23 & $5-9$ & $0.18-3.17$ & $0.087-3.2$ & 0.10 .92 \\
\hline $\mathrm{Gd}$ & $18.33-65.37$ & 33.5 & $5.71-15.00$ & 10.08 & $0.2-12.5$ & 5.27 & $57-131$ & $1.7-5.9$ & $4.0-20.7$ & $2.41-5.98$ \\
\hline $\mathrm{Tb}$ & $2.81-9.41$ & 5.0 & $0.89-2.62$ & 1.71 & $<0.1-2.6$ & 1.03 & N/A & $0.3-1.2$ & $0.47-5.21$ & $0.5-0.86$ \\
\hline Dy & $15.96-51.39$ & 27.5 & $4.48-15.2$ & 9.54 & $0.4-17.5$ & 5.49 & $40-62$ & $1.2-6.8$ & $1.9-35.1$ & $2.23-5.88$ \\
\hline Ho & $2.94-9.83$ & 5.3 & $0.76-2.95$ & 1.80 & $<0.1-3.5$ & 1.23 & $8-10$ & N/A & $0.25-6.88$ & $0.39-1.31$ \\
\hline $\mathrm{Er}$ & $8.21-26.46$ & 14.6 & $1.94-7.98$ & 4.95 & $0.2-3.5$ & 3.09 & $23-26$ & N/A & $0.62-22.8$ & $1.22-4.21$ \\
\hline $\mathrm{Tm}$ & $1.13-3.52$ & 2.0 & $0.28-1.19$ & 0.76 & $<0.05-1.45$ & 0.53 & N/A & $0.2-0.9$ & $0.09-4.33$ & N/A \\
\hline $\mathrm{Yb}$ & $7.11-20.2$ & 12.2 & $1.72-7.45$ & 4.70 & $0.3-9.6$ & 3.2 & $15-17$ & $0.8-4.6$ & $0.58-28.6$ & N/A \\
\hline $\mathrm{Lu}$ & $1.01-2.84$ & 1.7 & $0.24-1.05$ & 0.66 & $<0.01-1.39$ & 0.56 & 2 & $0.21-0.64$ & $0.085-4.12$ & $0.03-0.21$ \\
\hline LREE & $713-2152$ & 1317 & $152-402$ & 267 & $6-282$ & 176 & N/A & N/A & N/A & $38-310$ \\
\hline HREE & $60-189$ & 117 & $16-53$ & 34 & $1-58$ & 19.92 & N/A & N/A & N/A & $9-17$ \\
\hline$\sum \mathrm{REE}$ & $773-2341$ & 1434 & $168-358$ & 301 & $7-291$ & 196 & N/A & N/A & N/A & $47-320$ \\
\hline $\begin{array}{ll}1 . & \mathrm{I} \\
\text { 2. } & \mathrm{C} \\
\text { 3. } & \mathrm{C} \\
\text { 4. } & \mathrm{I} \\
\text { 5. } & \mathrm{C} \\
6 . & \mathrm{I} \\
\text { 7. } & \mathrm{I}\end{array}$ & $\begin{array}{l}\text { rnblende biotite } \\
\text { anites of Dingnar } \\
\text { anites of Komu a } \\
\text { cambrian alkali } \\
\text { anites from Gugu } \\
\text {-African Granite } \\
\text { samba granitic r }\end{array}$ & $\begin{array}{l}\text { nites of } \\
\text { outher } \\
{[34] \text {. }} \\
\text { nite, A } \\
\text { i and T } \\
\text { rom Ot } \\
\text { s in So }\end{array}$ & $\begin{array}{l}\text { he present stu } \\
\text { hina [20]. } \\
\text { ian shield [5] } \\
\text { dua area [32]. } \\
\text { h Sulaweau [3? }\end{array}$ & nesia & & & & & & \\
\hline
\end{tabular}




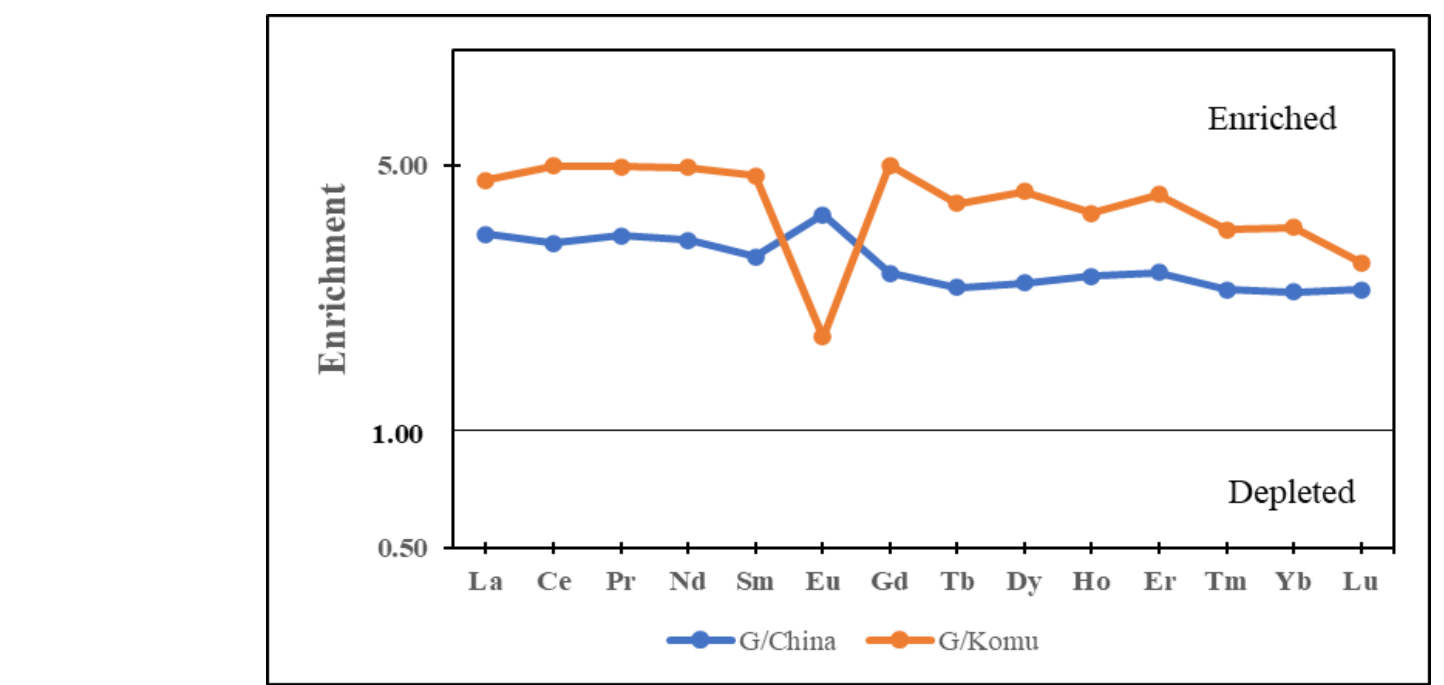

Fig.7. Enrichment plot for the rare earth elements in the granitoids of the study area (G- granitoids of the study area, China and Komu-Reference values).

\section{CONCLUSION}

The granitoids in the study area occur in the western part of the study area with the granite gneiss occurring as low lying and the hornblende biotite granite occurring as plutons in the southwestern part of the area. The NE-SW foliation trends of the granitoids in the study area is typical of the PanAfrican orogeny. Petrography and geochemistry data revealed considerable similarities in the studied rock units.

REEs geochemistry revealed that the coarse-grained granite (porphyritic granite) had REE concentrations greater than those in the granite gneisses. Generally, the REE distribution pattern showed enrichment in light rare earth elements, depletion in heavy rare earth elements and negative Europium anomaly. These geochemical signatures suggest fractional crystallization, plagioclase fractionation and possibly crustal contamination as all the samples analyzed had values above 1 relative to the REE chondrite values.

In comparison to the REE concentrations of granitoids from other areas in and outside Nigeria, the REE concentrations of the granitoids in the study area are significantly higher. Also, the abundance of the REEs in the granites compared to the concentrations from areas where REEs are been mined suggests that the coarse-grained granites in the study area have potential for REE mineralisation.

\section{ACKNOWLEDGMENT}

The authors acknowledge the African Union Commission through Pan African University Life and Earth Science, University of Ibadan, Nigeria for their financial aid during this research. The authors are also grateful to the reviewers for their critical contributions towards improving the quality of this article.

\section{REFERENCES}

[1] Roskill, The Economics of Rare Earths and Yttrium, vol. XIII, London: Roskill Information Services, Ltd,, 2007, p. 275.

[2] A. R. Woolley, Alkaline Rocks and Carbonatites of the World. Part 1: North and South America., Austin: University of Texas Press, 1987.

[3] F. Wall and A. N. Mariano, "Rare earth minerals in carbonatites: A discussion centred on the Kangankunde carbonatite, Malawi.," in Rare Earth Minerals: Chemistry, Origin, and Ore Deposits., A. Jones, F. Wall and C. Williams, Eds., London, Chapman and Hall, 1996, p. 193-225.

[4] G. J. Orris and R. I. Grauch, "Rare Earth Element Mines, Deposits, and Occurrences.," USGS, Reston, VA, 2002.

[5] A. Drysdall, N. J. Jackson, C. R. Ramsay, C. J. Douch and D. Hackett, "Rare elements mineralisation related to precambrian Alkali granite in the Arabian Shield," Economic Geology, vol. 79, pp. 1366-1377, 1984.

[6] X. Ren, "A brief account of rare earth mineralisation in China.," in New Frontiers in REE Science and Applications, Q. Xu., Ed., Beijing, China Science Press, 1985, p. 39-41.

[7] W. C. Overstreet, "The Geologic Occurrence of Monazite," USGS, Reston, VA, 1967.

[8] I. I. Dilioha and J. N. Onwualu-John, "The Economic Potentials of the Rare Earth Elements in the Basaltic Rocks of Ameta, Southern Benue trough Nigeria," Journal of Enviromental and Analytical Toxicology, vol. 6, no. 4, pp. 1-5, 2016.

[9] M. O. Oyawoye, "Basement Complex of Nigeria," in African Geology, Ibadan, University Press, 1972, pp. 62-98.

[10] P. McCurry, "The geology of the Precambrian to lower Paleozoic rocks of nothern Nigeria; a review.," in Geology of Nigeria , C. A. Kogbe, Ed., Lagos, Elizabeth Publication Company, 1976, pp. 15-39.

[11] M. A. Rahaman, "Recent advances in the study of the Basement Complex of Nigeria.," in Precambrian Geology of Nigeria, P. O. Oluyide, W. C. Mbonu, A. E. O. Ogezi, I. G. Egbuniwe, A. C. Ajibade and A. C. Umeji, Eds., Kaduna, Nigerian Geological Survey., 1988, p. $11-43$.

[12] S. S. Dada and M. A. Rahaman, "Archean-Lower Paleozoic Crustal evolution in Nigeria," African Geoscience Review, vol. 2, no. 19, pp. 43-58, 1995.

[13] M. Woakes, M. Rahaman and A. and Ajibade, "Some metallogenic features of the Nigerian Basement," Journal of African Earth Sciences, vol. 6, pp. 655-664, 1987.

[14] A. A. Elueze, "Geochemistry and Petrotectonic setting of metasedimentary rocks of the schist belt of Ilesa area, southwestern Nigeria.," Journal of Mining and Geology, vol. 18, no. 1, pp. 194-197, 1981.

[15] A. A. Beus and S. V. Grigorian, Geochemical exploration methods for mineral deposits., USA: Applied Publishing Limited, 1977. 
[16] A. A. Elueze, "Mineralogy and chemical nature of meta-ultramafites in Nigerian schist belts.," Journal of Mining and Geology, vol. 19, p. 21-29, 1982

[17] A. A. Elueze and A. T. Bolarinwa, "Petrochemistry and petrogenesis of granitic rocks in Abeokuta area, southwestern Nigeria.," Journal of Mining and Geology., vol. 40, no. 1, pp. 1-8, 2004.

[18] S. M. Elatikpo, U. A. Danbatta and T. Najime, "Geochemistry and Petrogenesis of Gneisses Around Kafur-Yari-Bori-Tsiga area within the Malumfashi Schist Belt, Northwestern Nigeria," Journal of Environment and Earth Science, vol. 3, no. 7, pp. 171-180, 2013.

[19] S. N. Lai, M. Pandey, A. Hyanki and D. Prakash, "Petrology and Geochemistry of Granitic Gneisses from Main Central Thrust (MCT) Zone, Kumaun Himalaya, India.," Himalayan Geology, vol. 32 , no. 2, pp. 137-147, 2011.

[20] S. Ishihara, R. Hua, M. Hoshino and H. Murakami, "REE Abundance and REE Minerals in Granitic Rocks in the Nanling Range, Jiangxi Province, Southern China, and Generation of the REE-rich Weathered Crust Deposits.," Resource Geology, vol. 58 , no. 4, pp. 355-372, 2008.

[21] O. A. Afolabi, "Geological mapping and geochemical characterisation of lithologic units in part of Sheet 243, Ilesha, Southwestern Nigeria.," Unpublished Ph.D. Thesis, University of Ibadan, Nigeria, 2017.

[22] O. S. Ayodele and C. A. Ajayi, "Petrology, mineralogy and geochemistry of the precambrian rocks around Ikere-Ekiti, southwestern Nigeria," Journal of Chemical and Petrochemical Technology, vol. 2, no. 1, pp. 1-24, 2016.

[23] S. R. Taylor, "Abundance of Chemical Elements in the Continental Crust: a new table," Geochimica et Cosmochimica Acta, vol. 28, pp. 1273-1285, 1964.

[24] J. Tarney, "Petrology, mineralogy and geochemistry of the Falkland Plateau basement rocks, Site 30, deep sea drilling project.," Initial report, vol. 36, pp. 893-920, 1977.

[25] E. A. K. Middlemost, "Naming materials in the magma/igneous rock system," Earth Science Review, vol. 37, pp. 215-224, 1994.

[26] S. J. Shand, Eruptive rocks, Their genesis, compositions, classification and their relation to ore-deposits with a chapter on Meteorite, 2nd ed., New York: John Wiley, 1943, pp. 1-444.

[27] J. A. Pearce, N. W. Harris and A. G. Tindle, "Trace element discrimination diagrams for the tectonic interpretation of granitic rocks," Journal of Petrology, vol. 25, pp. 956-983, 1984.

[28] J.-P. Lie'geois, J. Navez, J. Hertogen and R. Black, "Contrasting origin of post-collisional high-K calc-alkaline and shoshonitic versus alkaline and peralkaline granitoids. The use of sliding normalization," Lithos, vol. 45, p. 1-28, 1998.

[29] S. F. Toteu, J. Penaye and D. Poudjom, "Geodynamic evolution of the Pan-African belt in central Africa with special reference to Cameroon.," Canadian Journal of Earth Science, vol. 41, p. 73-85, 2004.

[30] W. V. Boynton, "Cosmochemistry of the rare earth elements: meteorite studies," in Rare Earth Element Geochemistry, P. Henderson, Ed., Amsterdam, Elsevier, 1984, pp. 63-114.

[31] M. Yuan, C. Liu, W. Liu, M. Guo, J. Morel, H. Huot, H. Yu, Y. Tang and R. Qiu, "Accumulation and fractionation of Rare Earth Elements (REEs) in the naturally grown Phytolacca Americana L. in southern China," International Journal of Phytoremediation, vol. 20, no. 5, pp. $415-423,2018$

[32] A. O. Olaolorun and O. A. Akintola, "Compositional Characteristics in Relation to the Evolution of Granite Suites in Guguruji Area, Parts of Ayetoro (Sheet $226 \mathrm{NW}$ and NE) and Kagara, Tegina (Sheet 142 SE), North-Central, Nigeria," International Research Journal of Advanced Engineering and Science, vol. 3, no. 3, pp. 80-90, 2018

[33] V. Ukaegbu and F. T. Beka, "Rare-earth elements as source indicators of Pan-African granites from Obudu Plateau, Southeastern Nigeria," Chinese Journal of Geochemistry, vol. 27, p. 130-134, 2008.

[34] O. H. Ajilore, "Geology and Rare Earth Elements Mineralisation of Granitoids in Ofiki and Environs, Komu Area, Southwestern Nigeria," Unpublished M.Sc. Thesis, University of Ibadan, Nigeria, 2018.

[35] D. G. Richardson and T. C. Birkett, "Peralkaline rock-associated rare metals," in Geology of North America , O. R. Eckstrand, W. D. Sinclair and R. I. Thorpe, Eds., Boulder, 1996, p. 523-540.

[36] P. L. Verplanck, B. S. Van-Gosen, R. R. Seal and A. E. McCafferty, "A Deposit Model for Carbonatite and Alkaline Intrusion-Related
Rare Earth Element Deposits," U.S. Geological Survey, Reston VA USA, 2014

[37] A. Maulana, K. Watanabe, A. Imai and K. Yonezu, "Petrology and Geochemistry of Granitic Rocks in South Sulawesi, Indonesia: Implication for Origin of Magma and Geodynamic Setting," International Journal of Geotechnical and Geological Engineering, vol. 6, no. 1, pp. 1-6, 2012.

[38] H. Rollinson, Using Geochemical Data: Evaluation, Presentation and Interpretation, Longman Group Ltd, 1993, p. 352.

[39] K. Wedepohl, "The composition of the continental crust," Geochimica et Cosmochimica Acta., vol. 59, no. 7, pp. 1217-1232, 1995.

[40] J. Tarney, "Geochemistry of Archaean high grade gneisses, with implications as to the origin and evolution of the Precambrian crust," in The early history of the earth. , B. Windley, Ed., London, Wiley, 1976, pp. 405-417. 